
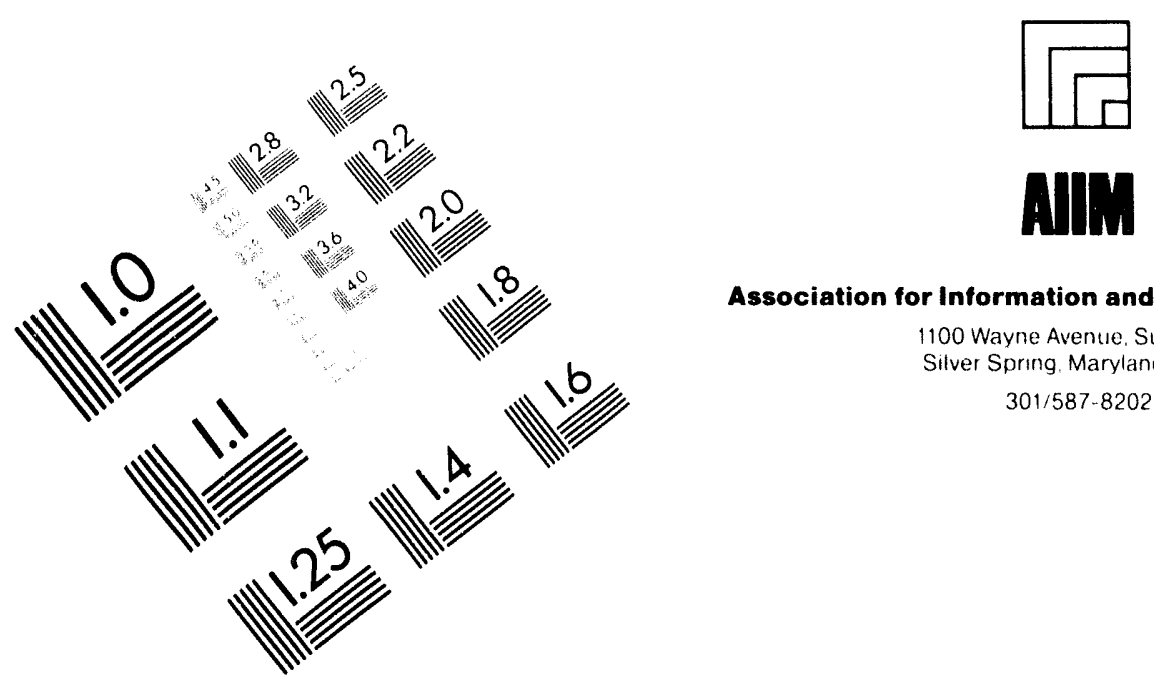

Association for Information and Image Management 1100 Wayne Avenue. Sutte 1100

Silver Spring Maryland 20910

301/587-8202

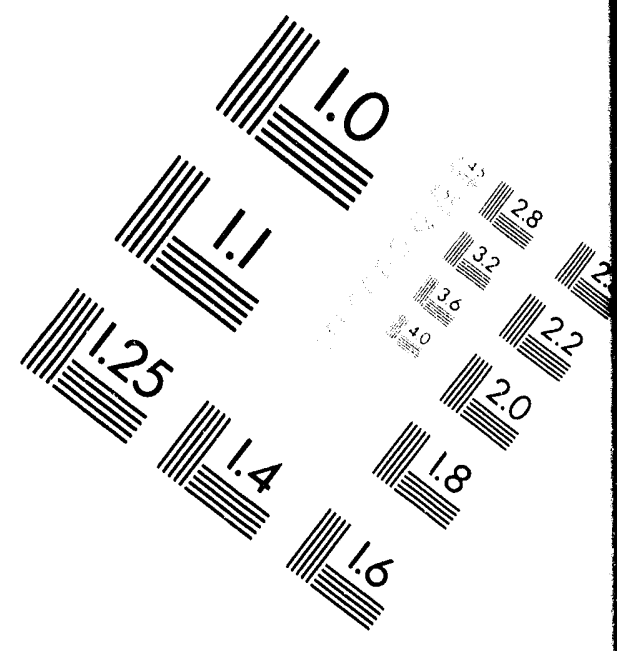

\title{
Centimeter
}

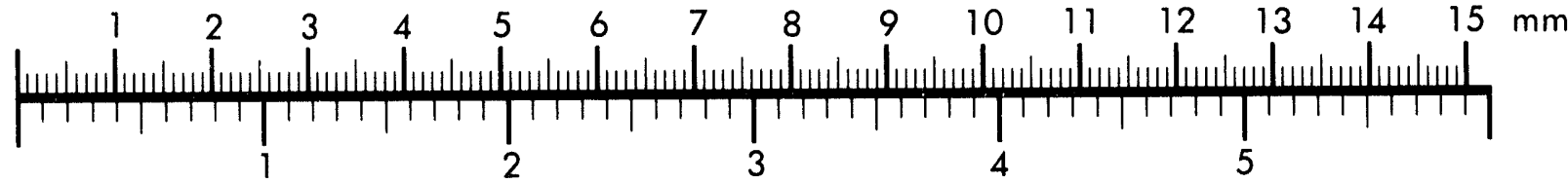

Inches
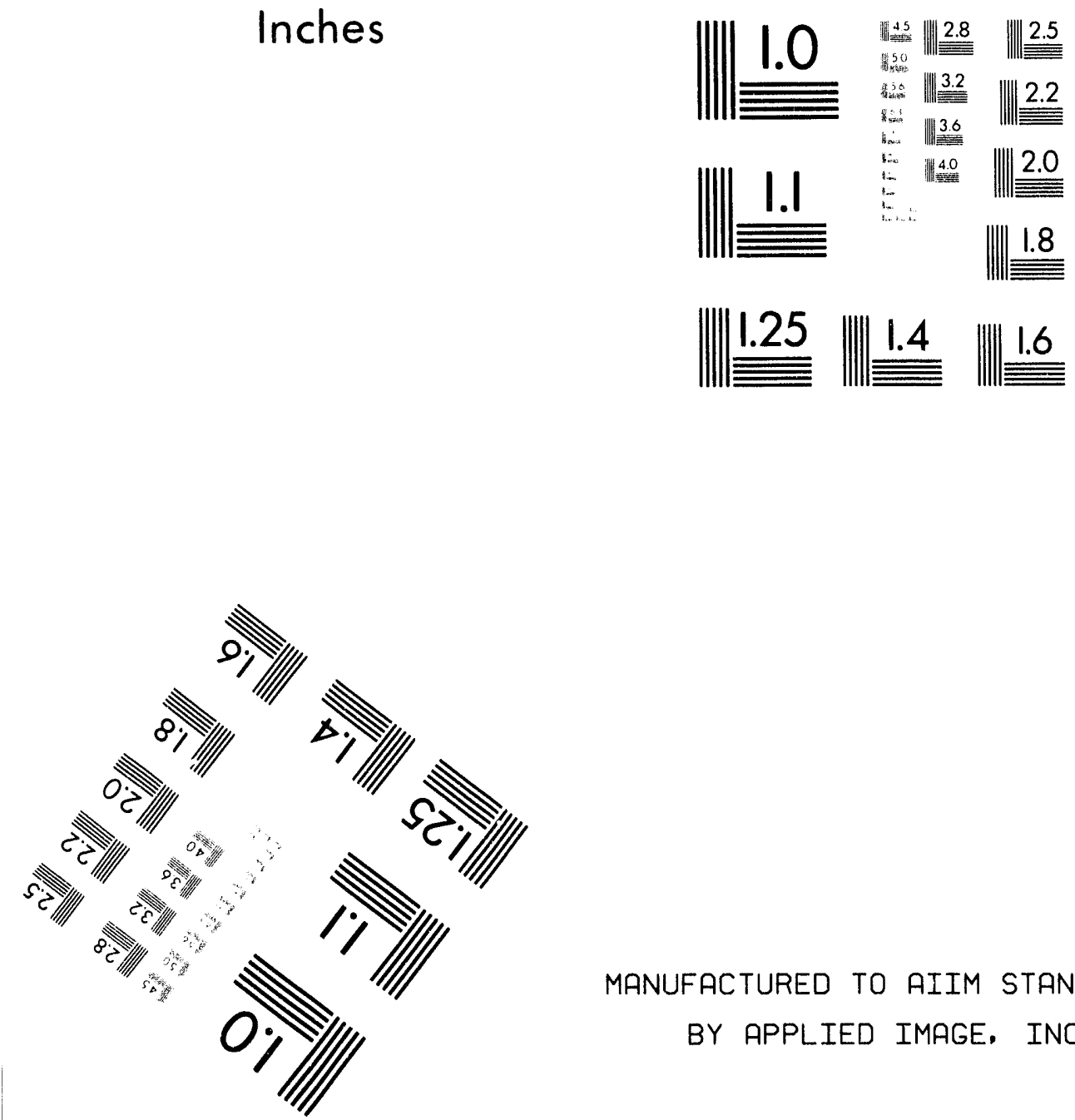

MANUFACTURED TO AIIM STANDARDS

BY APPLIED IMAGE, INC.

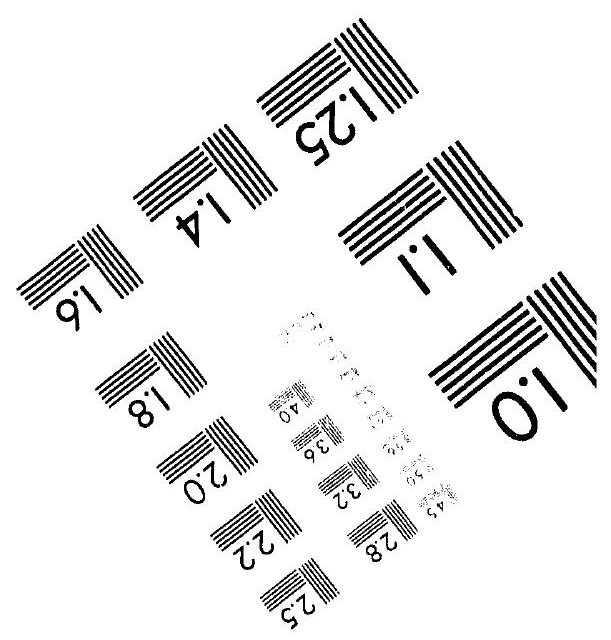



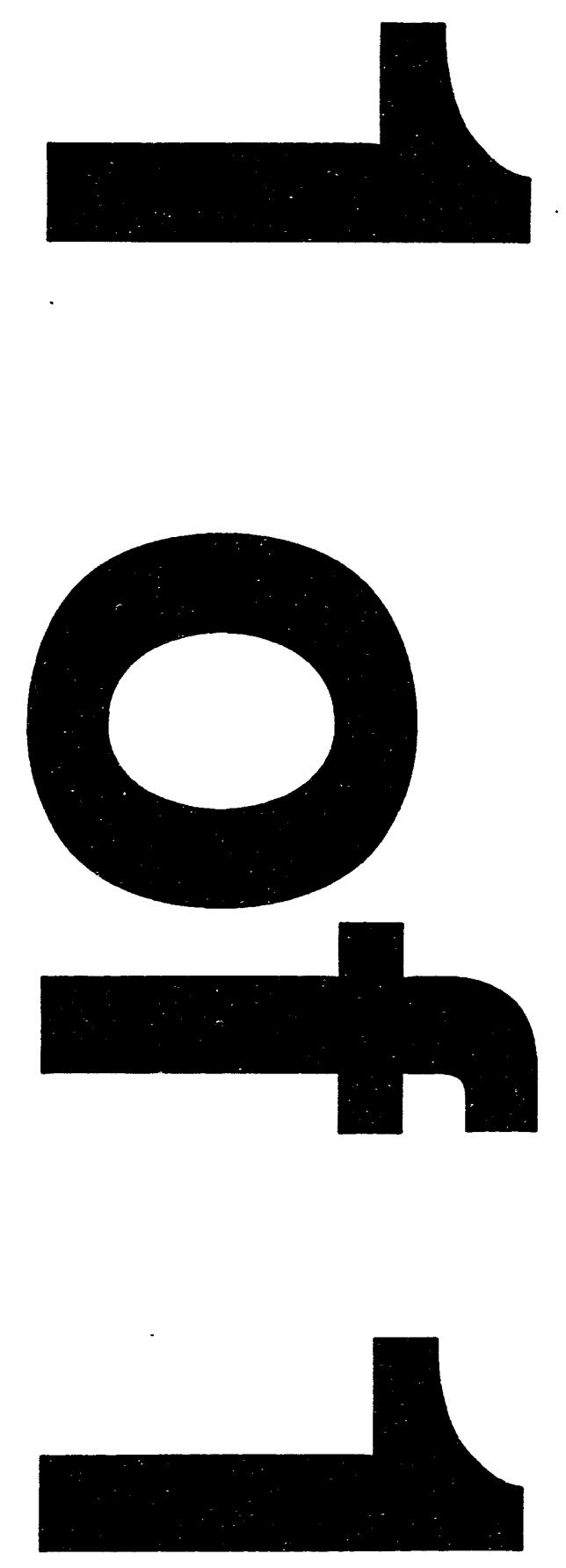


\section{SRTC CRITICALITY SAFETY TECHNICAL REVIEW: PHASE I CRITICALITY ANALYSIS FOR THE 9972-9975 FAMILY OF SHIPPING CASKS (U); (SRT-CMA-940003)}

by

Roy Rathbun

Westinghouse Savannah River Company

Savannah River Site

Aiken, South Carolina 29808

\section{DOE Contract No. DE-AC09-89SR18035}

This paper was prepared in connection with work done under the above contract number with the U.S.

Department of Energy. By acceptance of this paper, the publisher and/or recipient acknowledges the U. S. Government's right to retain a nonexclusive, royalty-free license in and to any copyright covering this paper, along with the right to reproduce and to authorize others to reproduce all or part of the copyrighted paper. 


\section{DISCLAIMER}

This report was prepared as an account of work sponsored by an ageacy of the United States Governmeat. Neither the United States Government nor any agency thereof, nor any of their employees, makes any warranty, express or implied, or assumes any legal liability or responsibility for the accuracy. completeness, or usefulness of any information. apparatus. product, or process disclosed, or represents that its use would not infringe privately owned rights. Refereace herein to any specific commercial product, process, or service by trade name, trademark, manufacturer, or otherwise does not necessarily constitute or imply its endorsement, recommendation, or favoring by the United States Government or any ageacy thereof. The views, and opinions of authors expressed berein do not necessarily state or reflect those of the United States Governmeat or any agency ihereof.

This report has been reproduced directly from the best available copy.

Available to DOE and DOE contractors from the Office of Scientific and Technical Information. P. O. Box 62. Oak Ridge. TN 37831: prices available from (615) $576-8401$.

Available to the public from the National Technical Information Service, U. S. Deparmeat of Commerce, 5285 Port Royal Rd., Springfield. VA 22161 
SAVANNAH RIVER TECHNOLOGY CENTER

Applied Technology Section

Applied Physics Group

SRT-CMA-940005

SRTC CRITICALITY SAFETY TECHNICAL REVIEW:

PHASE I CRITICALITY ANALYSIS FOR THE 9972-9975 FAMILY OF

SHIPPING CASKS (U):(SRT-CMA-940003)

March 2, 1994

Reviewer: H.W. Kaflem

Roy Rathbun, ext. 58232

Applied Physics Group/Criticality Analysis

Approvals:

Task Leader, APG

Criticality Analysis and Training

Manager, Applied Physics Group (APG)

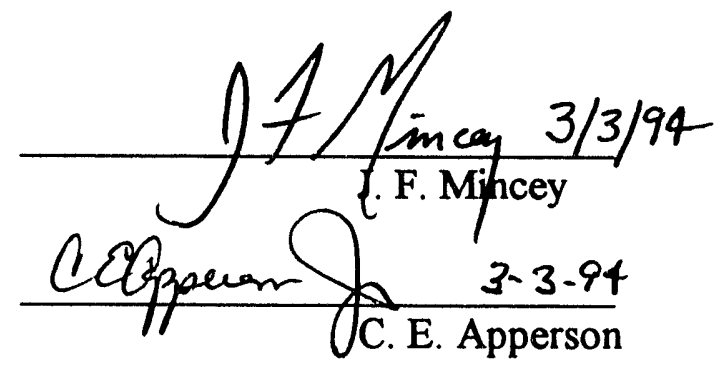

UNCLASSIFIED

DOES NOT CONTAIN UNCLASSIFIED CONTROLLED

NUCLEAR INFORMATION

Reviewing

Official:

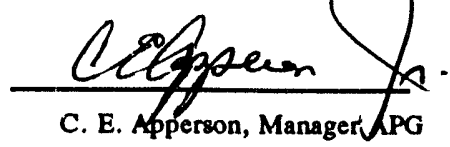

Date:

$3-3-94$

Distribution:

R. L. Frost

P. J. Vescovi

R. L. Reed

M. R. Buckner,

J. F. Mincey

APG Files/Kaye Summers

786-1A

773-22A

E. F. Trumble

786-1A

$773-42 \mathrm{~A}$

J. F. Zino

$773-22 A_{\text {RWR }}$

$773-42 \mathrm{~A}$

C. E. Apperson

773-22A

T, G. Williamson

$773-4 Z A 24 A$

$773-42 A R w R$ Technical Information Mgmt 703-43A 
SRT-CMA-940005

Page 2 of 6

SUMMARY

Review of SRT-CMA-940003, "Phase I Criticality Analysis For The 9972-9975 Family Of Shipping Casks (U); (SRT-CMA-940003)," January 22,1994, has been performed by the SRTC Applied Physics Group. The NCSE is a criticality assessment of the 9972-9975 family of shipping casks. This work is a follow-on of a previous criticality safety evaluation, with the differences between this and the previous evaluation are that now wall tolerances are modeled and more sophisticated analytical methods are applied.

The NCSE under review concludes that, with one exception, the previously specified plutonium and uranium mass limits for 9972-9975 family of shipping casks do ensure that WSRC Nuclear Criticality Safety Manual requirements (ref. 1) are satisfied. The one exception is that the plutonium mass limit for the 9974 cask had to be reduced from 4.4 to $4.3 \mathrm{~kg}$. In contrast, the $7.5 \mathrm{~kg}$ uranium mass limit for the 9974 cask was raised to 14.5 $\mathrm{kg}$, making the uranium mass limit identical for all casks in this family.

After a thorough review of the NCSE, this reviewer agrees with all conclusions stated therein.

\section{SCOPE OF TECHNICAL REVIEW}

This technical review consisted of:

an independent check of the methods and models employed, application of ANSI/ANS 8.1 and 8.15, verification of WSRC Nuclear Criticality Safety Manual(1) procedures.

DOCUMENTATION

Issuance of this :nemorandum transmits this technical review as critical data.

METHOD AND MODEL REVIEW

\section{Method:}

\section{Cross-Sections}

Hansen-Roach 16-Group Cross-Section Data Library

This library is an extensively utilized database used for criticality safety analysis that is installed and verified on the SRS IBM mainframe computer.

\section{SCALE Library}

This library is an extensively utilized database for criticality safety analysis developed at ORNL and is installed and verified on the SRS Cray mainframe computer. 


\section{Computer Codes}

Three sets of computing codes were utilized for the NCSE under review, and are listed here;

\section{HRXN/TWOTRAN}

Cross-section preparation and processing for this set of tools was performed with the Joshua 70 version of HRXN. The 16-group Hansen-Roach library is processed. This is a validated code developed at SRS.

TWOTRAN is a 2-dimensional, neutron transport theory criticality code. The validated $\mathrm{J} 70$ version was employed.

\section{DORT}

This is a neutron transport theory criticality code similar to TWOTRAN. This code developed at ORNL and is installed and verified on the SRS Cray mainframe computer. The SCALE cross section data is employed with DORT.

\section{HRXN/JSWL/KENO-V.a}

Cross-section preparation and processing was performed with the Joshua 70 versions of HRXN and JSWL. These are validated codes developed at SRS. The system keff is predicted with KENO-V.a, an SRS validated Monte Carlo criticality calculational code developed at Oak Ridge National Laboratory as part of the SCALE package.

These codes are widely used throughout the industry for performing criticality safety calculations.

\section{Model:}

The materials and dimensions used in all calculations were provided to this reviewer in microfiche form. The drawings upon which all this data was generated were also provided. These sources were thoroughly checked and were seen to be ccnsistent, with only one exception. This exception was corrected, re-calculated and shown to have an insignificant impact on the originally calculated keff.

\section{EVALUATION}

Data to perform this evaluation were derived from the NCSE under review, from references listed in the NCSE, and from private communications with the author. 
SRT-CMA-940005

Page 4 of 6

808080 NCSE CONTENT EVALUATION $\cos 0808$

\section{Bias Applied, Subcritical Margin and K-Safe:}

For uranium limit calculations;

Standard Bias: The bias applied is 0.03 , the maximum for uranium systems predicted with the HRXN/ANISN criticality method, which are deemed to apply to HRXN/TWOTRAN and HRXN/KENO-V.a calculations since these code package methodologies are nearly equivalent.

Non-uniformity Bias: The NCSE assumes full-flooding and unguaranteed fissile material distribution. Since the calculations are performed for uniform distribution, additional margin is added to account for non-uniform distribution of materials that can potentially yield higher keff's. The bias applied is 0.02 , deemed to be conservative. This margin is applied in lieu of performing actual non-uniform calculations. For the solid metal cases, this additional margin does not apply, since fissile materials are at their maximum density throughout the unit in question.

Subcritical Margin: The subcritical margin imposed for both normal and accident conditions is $0.05 \Delta \mathrm{k}$, which is a commonly used value for criticality evaluations.

K-safe: The K-safe used for the NCSE is 1.000-0.030(standard bias)-0.020(nonuniform bias) -0.050 (margin) $=0.900$ for solutions and 0.920 for the solid metal cases. Thus, the $k$-eff predicted for acceptable configurations will be less than or equal to this value.

For plutonium limit calculations;

Standard Bias: The bias applied is 0.01 , the maximum for plutonium systems predicted with the HRXN/ANISN criticality method, which are deemed to apply to HRXN/TWOTRAN and HRXN/KENO-V.a calculations since these code package methodologies are nearly equivalent.

Non-uniformity Bias: Same as uranium, see above.

Subcritical Margin: Same as uranium, see above.

K-safe: The K-safe used for the NCSE is 1.000-0.010(standard bias)-0.020(nonuniform bias) -0.050 (margin) $=0.920$ for solutions and 0.940 for the solid metal cases. Thus, the k-eff predicted for acceptable configurations will be less than or equal to this value.

It should be noted that for the KENO calculations, 3 standard deviations ( $\sigma$ ) are always added to the nominal keff. 


\section{Application of ANSI/ANS Standards:}

The NCSE uses equivalencies for isotopes other than the dominant ones, U-235 and Pu239.

The substitutions used are:

U-235 in place of U-234, U-232 or U-236;

U-238 not included;

$\mathrm{Pu}-239$ is substituted for $\mathrm{Pu}-240$ and $\mathrm{Pu}-241$, provided that $\mathrm{Pu}-240$ is greater than $\mathrm{Pu}-241$.

These substitutions are in accord with ANSI/ANS Standards 8.1 and 8.15.

\section{Review of NCSE Conclusions:}

The NCSE under review concludes that, with one exception, the previously specified plutonium and uranium mass limits for $9972-9975$ family of shipping casks do ensure that WSRC Nuclear Criticality Safety Manual requirements (ref. 1) are satisfied. The one exception is that the plutonium mass limit for the 9974 cask had to be reduced from 4.4 to $4.3 \mathrm{~kg}$. In contrast, the $7.5 \mathrm{~kg}$ uranium limit mass limit for the 9974 cask was raised to $14.5 \mathrm{~kg}$, making the uranium mass limit identical for all casks in this family. The following is an assessment of how that conclusion was reached.

\section{Normal conditions:}

All calculations were performed under accident conditions.

\section{Accident conditions:}

All calculations were performed under fully flooded conditions, i. e., water inside the casks and at least a one foot water reflector in all directions. It is assumed that there are no controls to prevent flooding, and hence, flooding could happen at any time the cask is loaded and in use. Additionally, a full range of cases were executed to ensure that optimally moderated configurations were covered.

Double contingency is addressed by stating that two independent administration checks must be placed on the fissile mass limit before a cask is loaded. This assumes that the uncertainty in scale measurement is taken into account. That being the case, it is fully demonstrated that while the fissile mass limit is adhered to, predictions for fully flooded casks do not exceed K-safe. This reviewer agrees with that conclusion. 


\section{INDEPENDENT CALCULATIONS $\operatorname{coc} 68 \mathrm{C}$}

Due to the extensive treatment by the NCSE author and the conservatism built into the accident scenarios, it was not felt that independent calculations were necessary.

\section{SAFETY MANUAL FORMAT AND PROCEDURES}

The WSRC Nuclear Criticality Safety Manual (ref. 1) describes certain requirements that are to be included in a specifically formatted NCSE. This section reviews the compliance with that document.

\begin{tabular}{|l|l|}
\hline \multicolumn{1}{|c|}{ SECTION } & \multicolumn{1}{c|}{ REMARKS } \\
\hline 1.0 Introduction: & Included with appropriate contents \\
\hline 2.0 Description: & Included with appropriate contents \\
\hline 3.0 Requirements Documentation & Included with appropriate contents \\
\hline 4.0 Methodology & Included with appropriate contents \\
\hline 5.0 Discussion of Contingencies & Included with appropriate contents \\
\hline 6.0 Evaluation of Results & Included with appropriate contents \\
\hline $\begin{array}{l}\text { 7.0 Administratively Controlled } \\
\text { Limits and Requirements }\end{array}$ & Included with appropriate contents \\
\hline 8.0 Summary and Conclusions & Included with appropriate contents \\
\hline 9.0 References & Included with appropriate contents \\
\hline
\end{tabular}

REFERENCES

1. WSRC Nuclear Criticality Safety Manual (U), WSRC-IM-93-13, Rev. 1, 7/1/93. 


\section{WESTINGHOUSE SAVANNAII RIVER COMPANY \\ INTER-OFFICE MEMORANDUM}

SRT.CMA. 940003

Phase I Criticality Analysis for the 9972.9975 Family of Shipping Casks

Date: January 22. 1994

Author:

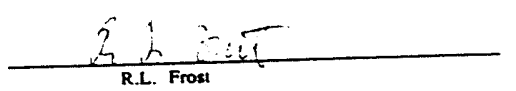

Approvals:

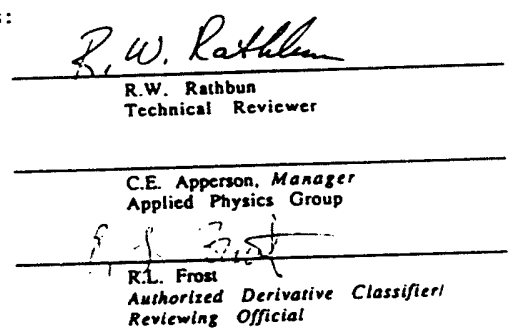

Distribution List:

$\begin{array}{llll}\text { C.E. Apperson } & 773-24 \mathrm{~A} & \text { E.K. Opperman } & 305-2 \mathrm{~A} \\ \text { J.F. Mincey } & 773-22 \mathrm{~A} & \text { R.S. Maurer } & 305-2 \mathrm{~A} \\ \text { R.E. Pevey } & 773-42 \mathrm{~A} & \text { APG File } & 773-24 \mathrm{~A} \\ \text { R.L. Frost } & 786-1 \mathrm{~A} & & \\ \text { K.A. Niemer } & 786-1 \mathrm{~A} & & \\ \text { E.F. Trumble } & 786-1 \mathrm{~A} & & \end{array}$

WESTINGHOUSE SAYANNAH RIVER COMPANY
SAFETY TECHNOLOGY DEPARTMENT

INTER-OFFICE MEMORANDUM

SRT.CMA. 940003

\section{Phase 1 Criticaliey Analysis for}

\section{To: R.S. Maurer}

From: R.L. Frost

1. INTRODUCTION AND SUMMARY

A criticality analysis of the $\mathbf{9 9 7 2 - 9 9 7 5}$ shipping casks has been performed that accounts for tolerances on pipe diameters and wall thicknesses as allowed in the ASTM standards. The previous crilicaliny analysis for these casks was performed using a max prev 5.10 in diameter for the Primary Conkernment Vessel (RCV) of s. in inches: an evaluation of the Aspropriate. The goal of the new analysis was to wirm that the mass of fissile material permitted by the previous work (Ref. 1) does indeed meet criticality safety requirements when the larger inner diameter of the PCV is taken into consideration. This required a re-analysis of the single flooded unit scenario. With one exception, it was found that the previous mass limits do indeed ensure criticality safety limits are not exceeded for the 9972.9975 series of shipping casks. The exception was for the The plutonium mass limil for has cask had in contrast the uranium mass (from $4.4 \mathrm{~kg}$ ) to ensure criticality safery. In cantast. $7.5 \mathrm{kz}$ to 14.5 The previous uranium limit was based on a physically unrealizable kg. The previ
geometry.

The previous analysis of the damaged array scenario remains valid. The revised SARP will reference the current work for the single flooded unit scenario and Ref. I for the damaged amay scenario. Note hal bod the current work and the previous analysis apply lo dy uren compounds that are predominanly $\mathrm{P}-23 \mathrm{~s}$ a In papticular, maserias compounds that are predo insenty pu-239. containing more than one nssle considered in phase 11 of this task. This analysis, they will. however. be conidance of Task 93-006-H-W.1.

This document is not intended to be a new SARP Chapter. and was not written 10 NRC Regulatory Guide 7.9 requirements. This memorandum 


\section{WESTINGHOUSE SAVANNAII RIVER COMPANY
SAFETY TECINOLOGY DEPARTMENT \\ INTER-OFFICE MEMORANDUM Phase 1 Criticality Analysis for \\ SGS.CMA. 940003
ST Page 3 of 34}

was written to transfer intermediate results. A new SARP chapter will be written after completion of phase 11 of this work. That document this memorandum as well as the phase II results.

\section{DESCRIPTION}

Shipping Cask Models

The objective of this work was to show that the criticality safety limits discussed above could not be exceeded with the currently allowed fissile nasses in the from the original analysis are given in Table 1. The first step in the current work was to prepare computer models for each of the shipping casks. The J70 version of TWOTRAN (Ref. 2) was used to calculate $k$-eff for each configuration considered in this work. The validation of TWOTRAN for these calculations is based on that for its 1-d counterpart. ANISN, and is reported in Refs. 3 and 4. Hansen-Roach cross sections were processed by HRXN (Ref. S) and used by TWOTRAN. Figures 1-8 show the TWOTRAN models ror tale drawing of the model casks used in this analysis. For med cask. a scale TWOTRAN model is is given, to orient the reader, and then a deted:

1. The Primary Containment Vessel (PCV) is made from 5 inch schedule 40 pipe. In order to maximize its volume (which maximizes the volume of fissile material). the maximum inner diameter permissible by ASTM standards (Ref. 6) was used in the TWOTRAN model. This maximum is found by appiying an allowed tolerance of $+1 / 16$ inch onto the nominal outer diamerer. and then decreasing the nominal wall thiskness by allowable $12.5 \%$. Nore this procedure also mingizes the PCV wall conservatism)

2. The Secondary Containment Vessel (SCV) is constructed of 6 inch schedule 40 pipe. Also. small lengths of 4 inch and 5 inch schedule 40 pipe are welded to the bottom of the PCV and SCV, respectively. to mate with the anti-rotation plate. Since none of these components restricts fissile volume. nominal dimensions were used.

\section{WESTINGHOUSE SAYANNAH RIVER COMPANY INTER-OFFICE MEMORANDUM} $\begin{array}{r}\text { Phase } 1 \text { Criticaliey Analysis for ... SR Page } 4 \text { of } 34 \\ \hline\end{array}$

3. The celotex insulation was assumed capable of absorbing enough water to become equal to water as a reflector. Thus, the celotex region is modeled as water.

4. The drum wall is not included in the models. This omission is made because their is such a large distance of water reflector between the difference in the results. Since the only difference between the 9972 9975 series of shipping casks and the $9965-9968$ series is in the drum wall material, omission of this detail also means that the results of this study are applicable to both series of shipping casks.

5. The modeling of the PCV and SCV was simplified to conform to the cylindrical geometry limitations of TWOTRAN. Where approximations would have a noticeable cfrect on the PSA PCY is a concave cap Modeling it as flat (making the PCV a perfeci right cylinder) increases the fissile volume and thus $k$-eff.

6. The bottom of the PCV contains an aluminum honeycomb spacer. This spacer was conservatively ignored (this increases the volume available for fissile solution), atthough the honeycomi spacers in the SCV were modeled.

7. No credit is taken for any type of packaging material inside the PCV.

8. The materials used in the analysis are listed in Table 2. The densities of atural uranium. $\mathrm{Pu}$-239. and aluminum honeycomb are the same as those used in the original work. HRXN was set up to adjust the natural uranium density to that of pure U-235. HRXN also calculated the isotopics for the uranium/water and plutonium/water homogeneous mixtures, and then produced the appropriate cross sections.

\section{REQUIREMENTS DOCUMENTATION}

The current work, along with that of the current SARP (ref. 1), meet the requirements of 10-CFR-71. NRC Reg. Guide 7.9. and DOE Order 5480.3. 


\section{WESTINGHOUSE SAVANNAH RIVER COMPANY
SAFETY TECHINOLOGY DEPARTMENT \\ INTER-OFFICE MEMORANDUM \\ Phase I Criticality Analysis for ...}

\section{METHODOLOGY}

Criticality Safety Limits

The analysis considers U.235 systems with concentrations ranging from pure metal to $1 \mathrm{~g}$ UR. Criticality safety limits for U-235 systems using HRXN-ANISN were reported in Ref. 3. The current calculations used HRXN-TWOTRAN: TWOTRAN is a 2-d counterpart to the 1-d ANISN, and it is assumed the HRXN-ANISN biases apply to HRXN-TWOTRAN. Ref. 3 provides 2 graph from which one can determine the required bias work it is necessery to ute the largess bins obenined over the H/U.235 range in the previous work (Ref. 1), this value was reported to be 0.025 . However, that value corresponds to an "eyeball fit" line throug the data: considering the actual data points. A value of 0.03 is appropriate. Reference 4 contains a similar graph for plutonium systems. This graph indicates a bias of 0.01 as being maximum across the $H /$ /rissile Pu range. and this reading is in agreement with the value reported in the previous SARP. In the previous SARP, a sub-critical allowable $k$-eff. This value was confirmed as being adequate in Ref. 7 . and is the value used in the current work.

The maximum allowable values of $k$-eff can be found by subtracting the bias and bias correction from 1.0. This results in an allowed $k$-eff for the U-235 systems of 0.92 , and 0.94 for the plutonium systems.

\section{Equivalences}

The work performed for this task considered two different materials: dry uranium material consisting primarily of U-235 and dry plutonitr amouns of U 232 U-234. and U-236 could be counted as 7 . suivalt U-235 on gram for gram basis in meeting the U.235 mass limis U. 238 does not count toward the mass limit. U-233 is not covered by the current work. For the plutonium material. small amounts of the other plutonium isotopes (non Pu-239) can be included in the Pu-239 mass limit if the following rules are adhered to:

\section{WESTINGHOUSE SAYANMAH RIVER COMPANY INTER-OFFICE MEMORANDUM} \begin{tabular}{l} 
Phase 1 Criticality Analysis for ... SES Pare 6 of 34 \\
\hline
\end{tabular}

1. The mass of Pu-240 and Pu-241 can be counted as equivalent on a gram for gram basis to Pu-239 if the Pu-240 mass
mass and if their sum is less than the Pu-239 mass.

2. Pu-242 can be treated equivalent to Pu-239 on a gram for gram basis if the Pu-241 mass exceeds the Pu-242 and if the sum of the Pu-

3. No equivalencies for Pu-238 or Pu-236 can be made.

These guidelines are outlined in References 4 and 7.

\section{Analysis}

The criticality analysis performed for the current work differs somewhat from the previous work. The latter used the ANISN code, a 1-d discrete ordinates code, to find the tissile mass limits. This was accomplished by first finding the critical radius, buckling. and and the calculaing the critical an inth from diameter and heighe This set of calculations was repeated over a wide concentration range of fissile solutions, to ensure that the optimal moderating conditions were found. The calculation performed in the first step used the proper wall thickness for the PCV. SCV. and shielding material (if any). but the volume of the PCV itself was varied as needed to contain the critical mass. The inside diameter was, however, limited to no greater than 5.10 inches. There are three points of interest here: 1. While the PCV diameter was limited, the beight was not. Therefore, critical volumes greater than the PCV volume were schieved in some mass limit than is needed for one of the cases considered.

2. The real geometry of the shipping casks was not maintained (radially or axially). 
WESTINGHOUSE SAVANNAH RIVER COMPANY

\section{INTER-OFFICE MEMORANDUM} SES.CMA 940003
SeT Page 7 of 34

\section{Phase 1 Criticality Analysis} 3. The analysis assumes separability of the axial and radial nux. This
assumption may not be valid for small fissile volumes.

4. Heterogeneous solutions were not considered.

In addition, the inner diameter limit on the PCV should be 5.174 inches as opposed to 5.10 inches. in order

The current analysis sought to address these issues. Two-dimensional discrete ordinates calculations were performed using TWOTRAN. The geometry of the shipping cask was always the same. with only the fissile solution geometry inside the PCV changing with concentration. Three types of TWOTRAN calculations had to be perforod. Sice the mass of fissile material was fixed (see Table be pasily calculated. In a fissile solution of a known concentration can be as PCV was filled with the fissile solution. In these cases, the fissile mass is less than the permitted limit. In cases where the fissile concentration is high enough that the fissile solution volume is less than the PCV volume, a cylinder of fissile solution with appropriate volume is centered within the PCV. and surrounded by water. Tables 3-7 are worksheets that break up the concentration range into three phases. The first range corresponds to complete filling of the PCV volume with fissile solution. ln the second range, the fissile cylinder has a radius equal to the PCV but a height less than the PCV height. In phase 3. the fissile cylinder is centered radially

5. DISCUSSION OF CONTINGENCIES

The current analysis, combined with that of Ref. 1, considered two

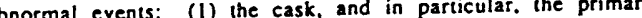
containment vessel, under flooded conditions (the single unit nooded analysis), and (2) an infinite array of damaged casks (damage is assumed to reduce the separation between hissile units). The analysis also investigated the casks under nord (Un it is not necessary 10 Because the fissile contents are in solin of the PCV. The cases envelope
WESTINGHOUSE SAVANNAH RIVER COMPANY INTER-OFFICE MEMORANDUM SET.CMA.940003

\section{Phase 1 Criticality Analysis for ...}

those required by 10-CFR-71 for fissile Class 1 packages.
sufficient to ensure criticality safety under all conditions.

\section{EVAlUation AND RESULTS}

The results of the TWOTRAN runs are shown in Figures 10 and 11 . As can be seen, the calculated $k$-eff is less than the critical limit for all of the casks for both the $\mathrm{U}-235$ 2nd Pu-239 cases. In all cases the curve of $k$-eff versus concentration has two maxima. The PCV volume (i.e.e. the concentration is equal to the mass limit divided by PCV volume). Any decrease in concentration from ihis point results in less fissile material inside the PCV, and thus k-eff decreases to the left of this maxima. Increasing the concentration beyond this point restlls in a decreaso fissile volume and thus increase in neutron leakage. At first, the increase in neutron leakage is more important than the increase in fissile concentration, and the k-eff decreases. A minimum is achieved at fissile concentration overshadows the increase in neutron leakage. This effect is more pronounced due to the large amount of reflection present in these systems. The second maxima is reached at the pure metal state. For the U-235 cases, the global maxima corresponded to the first peak for the 9972,9974 and 9975 casks, and to the second peak for the 9973 cask. The global maxima was the second peak for all of the plutonium cases.

Note that the $k$-eff versus concentration curve for the 9974 cask with -235 is very much lower than that for the other casks. This is due to the much lower mass limit placed on the U-235 in this cask $(7.5 \mathrm{~kg}$ versus $14.5 \mathrm{~kg}$ for the other casks). This limit was imposed due to the

very low critical mass of this system at very small concentrations.

Recall that the methodology used in Ref. 1 for finding the mass limit placed no limit on the fissile volume. It turns out that the 7.5

limit was based on 2 point on the curve of fissile mass versus concentration that results in a' fissile volume far greater than . Since the volume (larger than the PCV volume by about a factor of 3). Sine this peak is not seen. 
WESTINGHOUSE SAVANNAR RIVER. COMPANY

INTER-OFFICE MEMORÁNDUM

SRT.CMA.940003

Phase I Critlealley Analysls for ... Page 9 of 34

\section{Verifying Calculations}

The 570 version of TWOTRAN has a maximum mesh cipability of 8000 cells. For casks as large as those modeled here this" results in a rather coarse mesh. In addition, since it is an old code without the modern acceleration routines, execution is very time consumitg quadrature order. It is desinble to run with a muche finer mesh and a higher quadrature order to confirm the calculationialseresults. This is not possible with 70 TWOTRAN; however, it is quilo easy to do with DORT. DORT is a modern 2-D discrete ordinates code that has recently been obtained from the Radiation Shielding and Information Center. It has been installed and certified on the SRS Cray (Ref.. 8). E.DORT was first set up to duplicate the TWOTRAN mesh and quadrature at each of the two maxima for all casks. The results resthement berween the TWOTRAN and DORT course mesh. St resuls. For both codes, :t: eigenvalue convergence eriteita thas $1.0 \times 10^{-1}$. It tis apparent the coois do not calculate the samo elgenviluo to within

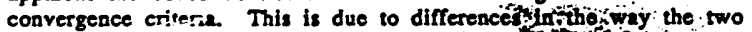
codes perform negative flux fixup, rebalancoif ceelention; and, the way they choose a starting direction. The minor discrepincies that ariso from these differences have been noted by other'enthiors: (Ref.' 9).

Table 8 indicates two cases in which the differences between coarse mesh TWOTRAN and coarse mesh DORT are much larger than the others other resuls and to indicate the DORT results are more accurnte. A review of the TWOTRAN input tumed up no errors. The suthor suspects that the TWOTRAN algorithm simply underpredicted $k$-eff in this casso dro to the very coarse mesh and the large amount of lead in the system

After verifying that DORT gives similas resuls to TWOTRAN when tho

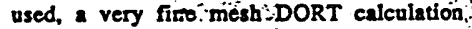
with $S_{16}$ quadranure was performed. The mesh spicing was calculated

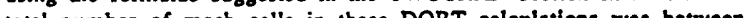

WESTINGHOUSE SAVANAAA RIVER COMPANY Y CAFETY TECRNOLOGY DEPARTMENT INTER-OFFICE MEMORANDUM SRT.CMA.940003
Page 10 of 34 Phase I Criticaliti Analisis for ... Page 10 100,000 and 150,000 Tho results of these calculations are also
tabulated in Tablot 8 . Note thist increasing the quadrature order

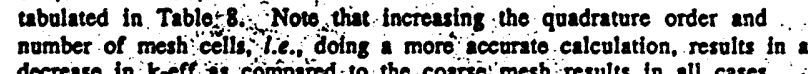

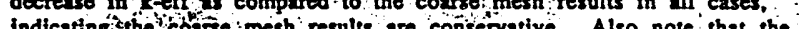
fine mest $D O R T$ T One rin Tables : $3-7$, For higher concentritions of fissile solution the sphere dismeter is imall enough to fit instace the PCV. However, it is not possible to model. aphere inside:a cylinder. with the discrete ordinates codes currently available at SRS. In spite. of this, it is important to consider the sphere case, since a sphere whilh havo a larger $k$-eft than $a$ cylinder of equal volume. Monte Carlg codes do not have the geometry limitations of discrete ordinates tedes, tend thas provide a means of analyzing. This

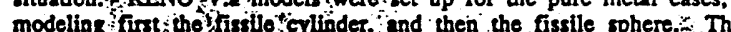
results ero thown in Tabie 9.0. If all of the KENO V.a cases 1200 batches

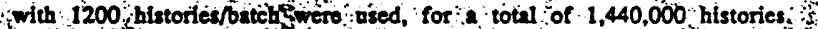

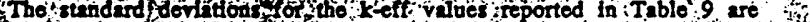

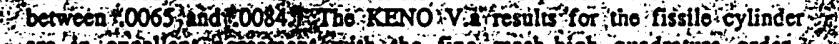
aro in excelfend greetente DORT calculations, is Indiezted in the table. The KENO V.a sphere resu are about 02 higher in $r$-eff than the cylinder results in all cases. However, the results are sthll somewhat below the critical limits in all cases. . It should be noted that the cylinders used in the analysis are no

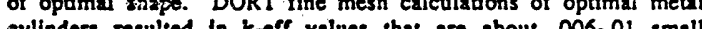
the sphero values. It was not necessery to consider optimal cylinders. however, sinco spheres wero analyzed, and spheres are always more reactive, than cylfiders. 
WESTINGHOUSE SAVANNAH RIYER COMPANY

INTER-OFFICE MEMORANDUM

Phase 1 Criticality Analysis for ... S27 Pags 11 of 34

Consideration of a Heterogeneous Geometry

The calculations discussed thus far have assumed the fissile material to be evenly distributed throughout the fissile volume: i.e.. a homogeneous mixture. It has been demonstrated through both experiment and calculation that the maximum $k$-eff of a solution occurs when the fissile material is heterogeneously distributed in a manner that results in hat neutron hax (Rer, U). Using Table vil or Ref. ll, one can

homogeneous distribution of a material will ensure that the maximum $k$-eff has been bounded, regardless of fissile material distribution. For the current work, it is appropriate to consider this addition at the poin of the first maximum in Figures 10 and 11. At the second maximum, the material is pure metal: redistributing it would only recreate the situation achieved at the first maximum. From Table 8. adding 02 10 the TWOTRAN values achieved al the first maximum results in a k-eff that is greater than the critical limit. However, as was shown above, the TWOTRAN values are overly conservalive due to the coarse mesh and Order DORT calculations, adding 0210 the values at the first maximum results in values that are still below the critical limit.

New Mass Limits

The value of $k$-eff at each of the two peaks must be below the critical limit to ensure criticality safety. As discussed above, this is true for all cases at the first maxima, even with the .02 factor added to account for heterogeneity. At the second maximum, the most reactive case is that of the fissile metal sphere. Since this case was analyzed with KENO V.a. it is necessary to add 30. where $\sigma$ is the standard deviation, to the value of $k$-eff, the result must still be below the critcal tim from the values in Table 9 , this is not the case for the

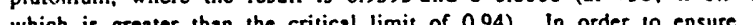
criticaliey safery for this cask, it was necessary to reduce the mass limil $1043 \mathrm{kB}$ (from $4.4 \mathrm{~kg}$ ), which results in a $k$-eff of 0.9365 and $\sigma 0009$. This value is still below the critical limit at $+3 \sigma$.
WESTINGHOUSE SAVANNAH RIVER COMPANY INTER-OFFICE MEMORANDUM

Phase 1 Criticaliey Analysis for ... SeF Page 12 of 34

It is also desirable to increase the uranium mass limit for the 9974 cask. As was discussed previously, the original value was based on a physically unrealizable geometry and Fssile volume. The DORT fine mesh calculation was repeated at the first maximum using a $14.5 \mathrm{~kg}$ mass limit (the old limit was $7.5 \mathrm{~kg}$ ). snd the uranium metal sphere

Table 10 lists the maximum values of $k$-eff obtained for each of the casks with U-235 and Pu-239. The maximum k-eff values reported in
this table are the larger of the two $k$-eff from the following cases:

1. The k-ff produced by DORT at the first maximum, plus .02 .

2. The $k$-eff produced by KENO V.a for the spherical metal fissiie mass. at the +30 limis.

The values for the 9974 cask correspond to the new mass limits for that cask. It turns cut that for the U-235 cases, the larger value occurs with cask. It turns cut that for the U-235 cases, the larger value occurs with
case 1 above. while with Pu-239, it occurs with case 2 . This is true for all four of the casks.

Note that in all cases, the maximum k-eff is below the critical limit.

The new mass limits are presented in Table 11 .

\section{ADMINISTRATIVELY CONTROLLED LIMITS AND} REQUIREMENTS As a requirement of this analysis, the amount of fissile material in a controls on this limit should follow the guidance of the double
colite contingency principle. with a minimum of two independent administrative checks of the fissile mass in a cask.

The uranium isotopes U-232, U-234, and U-236 can be counted as equivalent to $U-235$ on a gram for gram basis in meeting the uranium 


\section{WESTINGHOUSE SAVANNAH RIVER COMPANY
SAFETY TECIINOLOGY DEPARTMENT \\ INTER-OFFICE MEMORANDUM \\ Phase I Criticality Analysis for \\ SRT Page 13 of 34}

mass limit. U-238 does not count toward the uranium mass limit. $U$ 233 in nat covered by the current analysis.

Small amounts of Pu-240. Pu-241, and Pu-242 can be counted as equivalent to Pu-239 on a gram for gram basis in meeting the
plutonium mass limit if the following rules are adhered to:

1. The mass of Pu-240 and Pu-24I can be counted as equivalent on a gram for gram basis to Pu-239 if the Pu-240 mass exceeds the Pu-24

2. Pu-242 can be treated equivalent to $P u-239$ on 2 gram for gram basis if the Pu-241 mass exceeds the Pu-242 and if the sum of the

$P u-236$ and Pu-238 are not covered by the current analysis.

8. SUMMARY AND CONCLUSIONS

A thorough single nooded unit analysis of the 9972-9975 shipping casks for dry uranium material consisting primarily of U-235 dry plutonium materials consisting primanily of Pu-239 has maintain criticality safety Both the uranium and plutonium mass limis for the 9974 cask have changed from the original values, while the limits for the remaining casks have not changed.

\section{WESTINGHOUSE SAYANNAH RIVER COMPANY INTER-OFFICE MEMORANDUM \\ Phase 1 Crilicalley Analysis for \\ SeT:CMA.940003}

\section{REFERENCES}

1. J.H. Dickson, NCSA 83-1: Safe Loadings for the 9965. 9966, 9967. 9968 Shipping Packages, DPSPU-83-272-66, Apr. 28, 1983. See also Rev. 1. Sept. 22, 1983.

2. A.N. Mallen, TWOTRAN2: A Two-Dimensional Transport Throry Code for JOSHUA. DPST-75-203. Jan. 7, 1975.

3. H.K. Clark, Subcritical Limits for Uranium-235 Systems. Nucl. Sci. \& Eng. 81, 351 (1982)

4. H.K. Clark, Subcritical Limits for Plutonium Systems. Nucl. Sci. \& Eng. 79. 65 (1981).

5. H.K. Clark, JOSHUA Nuclear Criticality Safery Modules, DPSTM-86700-3. Mar. 1987.

6. ASTM A 530/A 530M-912, Siandard Specification for General Requirements for Specialized Carbon and Alloy Steel Pipe, approved Jul. 15. 1991.

7. J.F. Mincey, Chapter 6 of the SARP for the 9965, 9966, 9967 and 9968 Containers (U). SRT-CMA-930029, May 28, 1993.

8. R.L. Frost, DORT Certification Package. WSRC-TR-94-022, Jan. 1994. 9. W.F. Miller. Jr.. R.E. Alcoufee. G.E. Bosler. F.W. Brinkley. Jr., and R.D. O'dell. A Timing Comparison of Two-Dimensional Discrete-Ordinates Codes for Cring Comparis in Williamsburg. VA.

10. G. Goentzel. Minimum Critical Mass and Flat Flux, J. Nucl. Energy 2. 193-201 (1956).

11. H.K. Clark. Effect of Distribution of Fissile Material on Critical Mass, Nucl. Sci. \& Eng. 24, 133-141 (1966). 


\section{WESTINGHOUSE SAVANNAH RIVER COMPANY \\ STER-OFFICE MEMORANDUM \\ Phase 1 Criticality Analysis for ... SRT Page 15 of 34}

\section{TABLE 1}

Previously Determined Shipping Cask

Mass Limits* From Ref.

\begin{tabular}{|c|c|c|}
\hline $\cos$ & \begin{tabular}{|c} 
Maximum \\
Uranium Mass \\
(kg $)$
\end{tabular} & $\begin{array}{c}\text { Maximum } \\
\text { Plutonlum Mass } \\
\text { (kg) }\end{array}$ \\
\hline $\begin{array}{ll}9972 & (9965) \\
9973 & (9966) \\
9974 & (9967)\end{array}$ & $\begin{array}{l}14.5 \\
14.5 \\
7.5 \\
1.5\end{array}$ & $\begin{array}{l}4.4 \\
4.4 \\
4.4\end{array}$ \\
\hline
\end{tabular}

-Note: The limits have changed as a result of the current analysis. Sec Table 11 .

TABLE 2

Materials Used in the Criticality Analysis

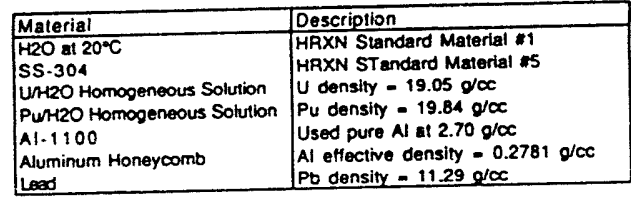

WESTINGHOUSE SAVANNAH RIVER COMPANY

INTER-OFFICE MEMORANDUM

Phase 1 Criticality Analysis for ... SeT Page 16 of 34

TABLE 3

Calculation Work heet for the 9972 and 9973 Casks with U.235 Aqueous Solution

\begin{tabular}{|c|c|c|c|c|}
\hline $\begin{array}{c}\operatorname{Conc} U^{-223 .} \\
(\ell \Omega)\end{array}$ & \begin{tabular}{|c|} 
Finsile \\
Volume (c)
\end{tabular} & $\begin{array}{l}\text { Cylindor } \\
\text { Redius }\end{array}$ & $\begin{array}{l}\text { Sphore } \\
\text { Redius }\end{array}$ & \\
\hline & & 6.57 & 15.13 & $\frac{1}{1}$ \\
\hline 1500 & 9667 & 6.57 & 13.21 & \\
\hline 2000 & 7250 & 6.57 & 1201 & \\
\hline 3000 & 4833 & 6.57 & $\begin{array}{l}10.49 \\
9.64\end{array}$ & \\
\hline 4000 & 3625 & 6.57 & 953 & a \\
\hline 5000 & 2000 & 6.57 & 8.85 & \\
\hline 6000 & 2217 & 6.44 & 8.32 & 피 \\
\hline 2000 & 2011 & 6.06 & 7.911 & \\
\hline 8000 & 1813 & $\begin{array}{l}5.76 \\
5.53\end{array}$ & $\begin{array}{l}7.56 \\
7.27\end{array}$ & \\
\hline 90000 & $\begin{array}{l}1611 \\
1480\end{array}$ & $\begin{array}{l}5.33 \\
5.32\end{array}$ & $\begin{array}{l}7.21 \\
7.02\end{array}$ & \\
\hline 11000 & $\operatorname{lan}_{1318}$ & 5.13 & 6.80 & \\
\hline 12000 & 1200 & 4.99 & 6.61 & \\
\hline 13000 & 1115 & 4.85 & 6.43 & \\
\hline 140000 & 1036 & 4.713 & 0 & \\
\hline 15000 & 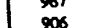 & $\begin{array}{l}4.03 \\
4.52\end{array}$ & 6.00 & \\
\hline 17000 & 853 & 4.43 & 5.88 & \\
\hline 18000 & 206 & 4.35 & $\operatorname{s.n}$ & \\
\hline 0000 & 763 & 4.29 & 5.67 & \\
\hline
\end{tabular}
Note: Approximate volume of the 9972 , 9973 , and $9974 \mathrm{PCV}$ as
modeled is $3761 \mathrm{~cm}^{3}$; the uranium mass limit for the 9972 and 9973 is $14.5 \mathrm{~kg}$ 
WESTINGHOUSE SAVANNAH RIVER COMPANY
SAFETY TECHNOLOGY DEPARTMENT

INTER-OFFICE MEMORANDUM Phase 1 Criticality Analysis for ... Se Page 17 of 34

TABLE 4

Calculation Worksheet for the 9974

Cask with U.235 Aqueous Solution

\begin{tabular}{|c|c|c|c|c|}
\hline Conc U.235 & \begin{tabular}{|l|} 
Finssite \\
\end{tabular} & Myindor & Sphorer & Type \\
\hline 1000 & \begin{tabular}{|l|l|}
75000 \\
\end{tabular} & 6.57 & \begin{tabular}{|l|}
12114 \\
\end{tabular} & 1 \\
\hline 15000 & $\frac{300}{3750}$ & $\frac{0.31}{6.57}$ & 9.64 & $\bar{I}$ \\
\hline 3000 & 2500 & 6.57 & 8.42 & \\
\hline 4000 & 1875 & 5.97 & 7.65 & 面 \\
\hline 5000 & 1500 & 5.49 & $\begin{array}{l}7.10 \\
6.68\end{array}$ & \\
\hline & $\frac{150}{1071}$ & $\frac{3.17}{4.87}$ & $\frac{0.06}{6.35}$ & \\
\hline 8000 & 938 & 4.62 & 6.07 & \\
\hline 9000 & 833 & 4.44 & 5.84 & \\
\hline 100000 & 750 & 4.27 & 3.64 & \\
\hline 11000 & 682 & $\begin{array}{l}4.12 \\
40\end{array}$ & $\begin{array}{l}5.46 \\
5.30\end{array}$ & \\
\hline 120000 & 60625 & $\begin{array}{l}4.00 \\
3.89\end{array}$ & $\begin{array}{l}5.30 \\
5.16\end{array}$ & \\
\hline $\begin{array}{l}13000 \\
14000\end{array}$ & $\begin{array}{l}577 \\
536\end{array}$ & $\begin{array}{l}3.79 \\
3.9\end{array}$ & $\begin{array}{l}3.100 \\
5.04\end{array}$ & \\
\hline 15000 & 500 & 3.72 & 4.92 & \\
\hline 16000 & 469 & 3.63 & 4.82 & \\
\hline 17000 & 44 & 3.56 & 4.72 & \\
\hline 18000 & 417 & 3.49 & 4.63 & \\
\hline
\end{tabular}

Note: Approximate volume of the 9972. 9973, and 9974 PCV as modeled is $3761 \mathrm{~cm}^{3}$.
WESTINGHOUSE SAYANNAH RIVER COMPANY
SAFETY TECHNOLOGY DEPARTMENT

INTER-OFFICE MEMORANDUM

INTER-OFFICE MEMORAN I Criticality Analysis for ... SRT Page 18 of 34
TABLE 5

Calculation Worksheet for the 9975

Cask with U.235 Aqueous Solution

\begin{tabular}{|c|c|c|c|c|}
\hline $\operatorname{Conc} \mathrm{U}_{-235}$ & Frusile & Cylinder & Sptorere & Type \\
\hline$(\mathbb{L})$ & Volume & Redius & Rediue & \\
\hline 1000 & 14500 & 6.57 & $\begin{array}{l}15.13 \\
13.21\end{array}$ & 1 \\
\hline 1500 & & 6.57 & 13.21 & \\
\hline $\begin{array}{l}2000 \\
2000\end{array}$ & $\begin{array}{l}7200 \\
7300\end{array}$ & $\begin{array}{l}6.57 \\
6.57\end{array}$ & $\begin{array}{l}1201 \\
10.88\end{array}$ & \\
\hline 3000 & 2833 & 6.57 & 10.49 & $\pi$ \\
\hline $\begin{array}{l}4000 \\
5000\end{array}$ & $\begin{array}{l}3625 \\
2000\end{array}$ & $\begin{array}{l}6.57 \\
6.57\end{array}$ & $\begin{array}{l}9.53 \\
8.85\end{array}$ & \\
\hline 8000 & 2217 & 6.44 & 8.32 & II \\
\hline $\begin{array}{l}7000 \\
2000\end{array}$ & $\begin{array}{l}2001 \\
1813\end{array}$ & $\begin{array}{l}6.08 \\
5.76\end{array}$ & 7.56 & \\
\hline 9000 & 1611 & 5.53 & 7.27 & \\
\hline 10000 & 1450 & 532 & 7.02 & \\
\hline 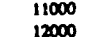 & 1318 & 5.13 & 6.80 & \\
\hline & 1115 & 4.85 & 6.43 & \\
\hline 10000 & 1036 & 4.73 & 6.28 & \\
\hline $\begin{array}{l}13000 \\
110000\end{array}$ & 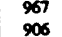 & $\begin{array}{l}4.63 \\
4.52\end{array}$ & $\begin{array}{l}6.13 \\
6.00\end{array}$ & \\
\hline 17000 & 853 & 4,43 & 5.88 & \\
\hline 18000 & 806 & 4.35 & $5 . \pi$ & \\
\hline 19000 & 763 & 422 & 5.67 & \\
\hline
\end{tabular}

Nore: Approximate volume of the 9975 PCV as modeled is $5385 \mathrm{~cm}^{3}$; the uranium mass limit for the 9975 is $14.5 \mathrm{~kg}$. 
WESTINGHOUSE SAVANNAH RIVER COMPANY

\section{NTER-OFFICE MEMORANDUM} SRT. SMA.940003 Phase 1 Criticality Analysis for

TABLE 6

Calculation Worksheet for the 9972, 9973, and 9974 Casks with Pu-239 Aqueous Solution

\begin{tabular}{|c|c|c|c|c|}
\hline $\begin{array}{c}\operatorname{Conc} \mathrm{U}^{-235} \\
(\mathrm{(LL})\end{array}$ & \begin{tabular}{|c|}
$\begin{array}{c}\text { Fissile } \\
\text { volume }\end{array}$ \\
\end{tabular} & $\begin{array}{l}\text { Cylindor } \\
\text { Redius }\end{array}$ & $\begin{array}{l}\text { Sphore } \\
\text { Redius }\end{array}$ & Type \\
\hline & & & & $T$ \\
\hline 1170 & 3761 & 6.57 & 9.65 & \\
\hline 1500 & 2933 & 6.57 & 8.88 & I \\
\hline 2000 & 2200 & 6.30 & 8.07 & IIII \\
\hline 3000 & 1467 & 5.50 & 7.05 & \\
\hline 4000 & 1100 & 5.00 & 6.40 & \\
\hline 5000 & 880 & 4.60 & 5.92 & \\
\hline $\begin{array}{l}60000 \\
7000\end{array}$ & $\begin{array}{l}733 \\
629\end{array}$ & $\begin{array}{l}4.33 \\
4.07\end{array}$ & $\begin{array}{l}5.59 \\
5.31\end{array}$ & \\
\hline $\begin{array}{r}0000 \\
8000 \\
8000\end{array}$ & $\begin{array}{l}6290 \\
550\end{array}$ & $\begin{array}{l}8.07 \\
3.87\end{array}$ & $\begin{array}{r}5.311 \\
5.08\end{array}$ & \\
\hline & 489 & 3.77 & 4.89 & \\
\hline 10000 & 10 & 3.58 & 4.72 & \\
\hline 11000 & 400 & 3.45 & 4.57 & \\
\hline 12000 & 367 & 3.35 & 4.44 & \\
\hline 13000 & 338 & 3.26 & 0.32 & \\
\hline 14000 & 314 & 3.18 & 4.22 & \\
\hline $\begin{array}{l}10000 \\
16000\end{array}$ & $\begin{array}{l}273 \\
275\end{array}$ & $\begin{array}{l}3.11 \\
3.04\end{array}$ & $\begin{array}{l}.12 \\
4.03\end{array}$ & \\
\hline 17000 & 259 & 2.98 & 3.95 & \\
\hline 18000 & 244 & 2.92 & 3.88 & \\
\hline 19840 & 222 & 2.84 & 3.75 & \\
\hline
\end{tabular}

Note: Approximate volume of the 9972,9973 and $9974 \mathrm{PCV}$ as

modeled is $3761 \mathrm{~cm}^{3}$. the piutonium mass limit for these casks is $4.4 \mathrm{~kg}$.
WESTINGHOUSE SAYANNAH RIVER COMPANY

SAFETY TECHNOLOGY DEPARTMENT INTER-OFFICE MEMORANDUM Phase I Criticality Analysis for ... SET Pape 20 of 34

TABLE 7

Calculation Worksheet for the 9975 Cask with Pu.239 Aqueous Solution

\begin{tabular}{|c|c|c|c|c|}
\hline Conc U-235 & $\begin{array}{l}\text { Fissile } \\
\text { Volume }\end{array}$ & $\begin{array}{l}\text { Cylundar } \\
\text { Redius }\end{array}$ & $\begin{array}{l}\text { Spherer } \\
\text { Redives }\end{array}$ & $T_{y p c}$ \\
\hline & & & & \\
\hline T. & 4000 & 6.57 & 10.17 & a \\
\hline 1500 & 2933 & 6.57 & 8.88 & \\
\hline 2000 & 2200 & 6.30 & 8.07 & $\overline{\mathrm{III}}$ \\
\hline 4000 & $\frac{1001}{1100}$ & $\frac{3.50}{500}$ & 6.40 & \\
\hline 5000 & $\infty$ & 160 & $s$ & \\
\hline 6000 & 73 & 4.33 & 5.59 & \\
\hline & & 4.07 & 5.31 & \\
\hline 8000 & $5 s 0$ & 387 & 3.08 & \\
\hline 9000 & 49 & 3.77 & 4.89 & \\
\hline 10000 & 40 & 3.58 & 4.7 & \\
\hline 1000 & & 3.45 & 4.57 & \\
\hline 120000 & 307 & 3.35 & 4.4 & \\
\hline 13000 & 338 & 3.26 & 4.32 & \\
\hline 14000 & & & & \\
\hline 130 & $\Delta$ & 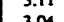 & 4 & \\
\hline imo & 2 & 298 & 399 & \\
\hline 18000 & $2 \mu$ & 2.92 & 388 & \\
\hline 19840 & 22 & 2.84 & 3.75 & \\
\hline
\end{tabular}

Note: Approximate volume of the $9975 \mathrm{PCV}$ as modeled is $5385 \mathrm{~cm}^{3}$. the plutonium mass limit for these casks is $4.4 \mathrm{~kg}$. 
WESTINGHOUSE SAVANNAH RIVER COMPANY
SAFETY TECINOLOGY DEPARTMENT

INTER-OFFICE MEMORANDUM Phase I Criticality Analysis for ... SET Page 21 of 34

TABLE 8

DORT Verifying Calculations

\begin{tabular}{|c|c|c|c|c|c|}
\hline & & Coar & Mosn Cat & Ulations & Fine Mest \\
\hline & 0,000 & TWOTRAN & DofT & Difterenc & \\
\hline 9972 & 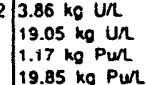 & $\begin{array}{l}0.9030 \\
0.8903 \\
0.8747 \\
0.935\end{array}$ & $\begin{array}{l}0.9085 \\
0.8889 \\
0.8737 \\
0.9322\end{array}$ & & $\begin{array}{l}0.8956 \\
0.8778 \\
0.8676 \\
0.9149\end{array}$ \\
\hline 9973 & $\begin{array}{l}3.86 \mathrm{~kg} \\
19.05 \mathrm{~kg} \\
1.17 \mathrm{~kg} \\
19.85 \mathrm{~kg}\end{array}$ & $\begin{array}{l}0.8786 \\
0.8911 \\
0.8497 \\
0.9363\end{array}$ & $\begin{array}{l}0.8767 \\
0.8891 \\
0.8477 \\
0.9335\end{array}$ & & $\begin{array}{l}0.9149 \\
0.8695 \\
0.8783 \\
0.0406 \\
0.9167\end{array}$ \\
\hline 9974 & $\begin{array}{l}19.85 \\
2.001 \\
19.05 \\
1.171 \\
19.85\end{array}$ & $\begin{array}{l}0.9363 \\
0.7917 \\
0.7469 \\
0.8756 \\
0.9326\end{array}$ & $\begin{array}{l}0.9335 \\
0.8497 \\
0.7692 \\
0.8736 \\
0.939\end{array}$ & $\begin{array}{l}0.0028 \\
-0.0580 \\
0.0223 \\
0.0018 \\
0.0080\end{array}$ & $\begin{array}{l}0.9167 \\
0.8432 \\
0.7507 \\
0.8669\end{array}$ \\
\hline 9975 & & & & & $\begin{array}{l}0.919 \\
0.8849 \\
0.8832 \\
0.8605\end{array}$ \\
\hline
\end{tabular}

WESTINGHOUSE SAVANMAH RIVER COMPANY

INTER-OFFICE MEMORANDUM

Phase I Criticality Analysis for ... Sef Pape 22 of 34

TABLE 9

KENO V.a Sphere Calculations

\begin{tabular}{|c|c|c|c|c|}
\hline & & DOAT Fine & & \\
\hline 9972 & 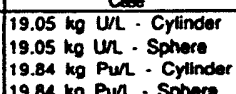 & $\begin{array}{l}0.8778 \\
0.9149\end{array}$ & $\begin{array}{l}\text { KanoVA } \\
0.8782 \\
0.8848 \\
0.9155 \\
0.0390\end{array}$ & $\begin{array}{l}-0.0004 \\
-0.0006\end{array}$ \\
\hline 9973 & $\mid \begin{array}{l}\mid 19.05 k \\
19.05 k \\
19.04 k \\
19.84 k\end{array}$ & $\begin{array}{l}0.8783 \\
0.9167\end{array}$ & & $\begin{array}{c}0.0006 \\
0.00009\end{array}$ \\
\hline 9974 & $\begin{array}{l}19.05 \\
19.05 \\
19.84 \\
19.84\end{array}$ & $\begin{array}{l}0.7507 \\
0.9219\end{array}$ & & $\begin{array}{c}0.0001 \\
0.0019\end{array}$ \\
\hline 997 & 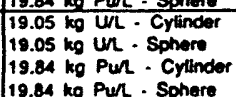 & $\begin{array}{l}0.8832 \\
0.9183\end{array}$ & $\begin{array}{l}0.9395 \\
0.8818 \\
0.8940 \\
0.9186 \\
0.9367\end{array}$ & $\begin{array}{c}0.0014 \\
.0 .0003\end{array}$ \\
\hline
\end{tabular}


WESTINGHOUSE SAVANNAH RIVER COMPANY
SAFETY TECINOLOGY DEPARTMENT

INTER-OFFICE MEMORANDUM

Phase 1 Criticality Analysis for ... SR Page 23 of 34

TABLE 10

Maximum k-eff Values Compared to Critical Limits

\begin{tabular}{|c|c|c|c|c|}
\hline & \multicolumn{2}{|c|}{$\quad 0.235$} & \multicolumn{2}{|c|}{$\frac{P_{y-239}}{P^{2}}$} \\
\hline$\frac{\cos \alpha}{9072}$ & $\frac{M a x k-a f f}{0.9156}$ & Critical Lim & Max $x \cdot e f$ & Critical Limil \\
\hline 9973 & $\frac{0.9166}{0.8895}$ & $\frac{0.9200}{0.9200}$ & $\frac{0.9364}{0.9381}$ & $\frac{0.9400}{0.9400}$ \\
\hline 9974 & 0.9143 & 0.9200 & 0.9391 & 0.9400 \\
\hline 9975 & 0.9049 & 0.9200 & 0.9399 & 0.9400 \\
\hline
\end{tabular}

TABLE 11

New Mass Limits for the 9972.9975 Casks

\begin{tabular}{|c|c|c|}
\hline Cask & $\begin{array}{c}\text { Maximum } \\
\text { Uranium Mass } \\
(\mathrm{ks})\end{array}$ & $\begin{array}{c}\text { Maximum } \\
\text { Plutonium } \\
(\mathrm{ks})\end{array}$ \\
\hline $9972(9965)$ & 14.5 & 4.4 \\
$9973(9966)$ & 14.5 & 4.4 \\
$9974(9967)$ & 14.5 & 4.3 \\
$9975(9968)$ & 14.5 & 4.4 \\
\hline
\end{tabular}

WESTINGHOUSE SAVANNAH RIVER COMPANY

INTER-OFFICE MEMORANDUM

Phase 1 Criticality Analveis for ... Sef Page 24 of 34

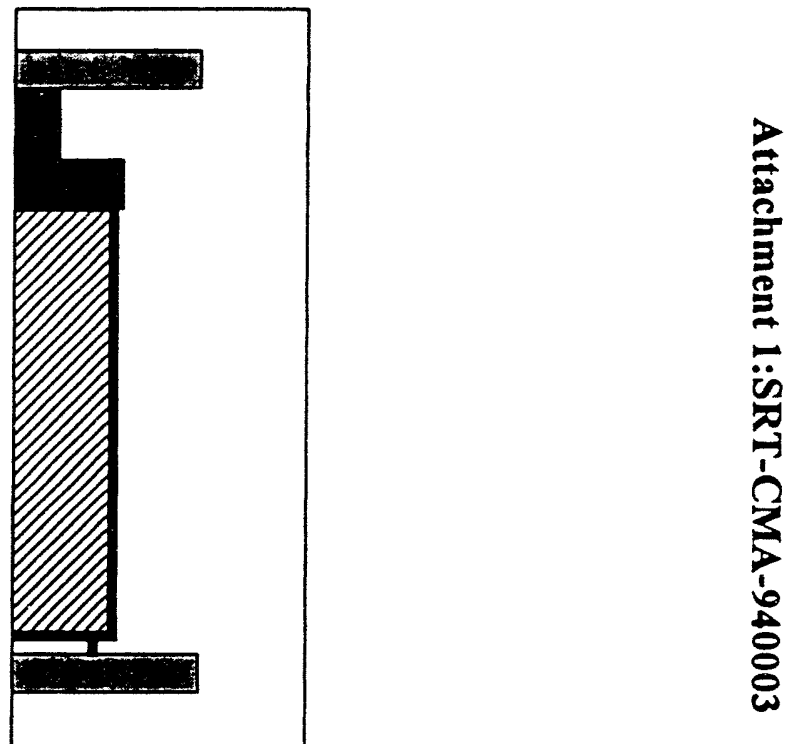

Figure 1. Model of the 9972 cask. The unshaded areas represent

water. The light shading indicates aluminum. the dark shading SS-304.

The composition and geometry of the interior of the PCV depends on the

case being modeled (see Figure 5). Everything out to the top and

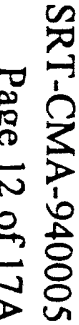


WESTINGHOUSE SAYANNAII RIVER COMPANY

INTER-OFFICE MEMORANDUM

\begin{abstract}
Sé Pase 25 of 34
Phase
\end{abstract}

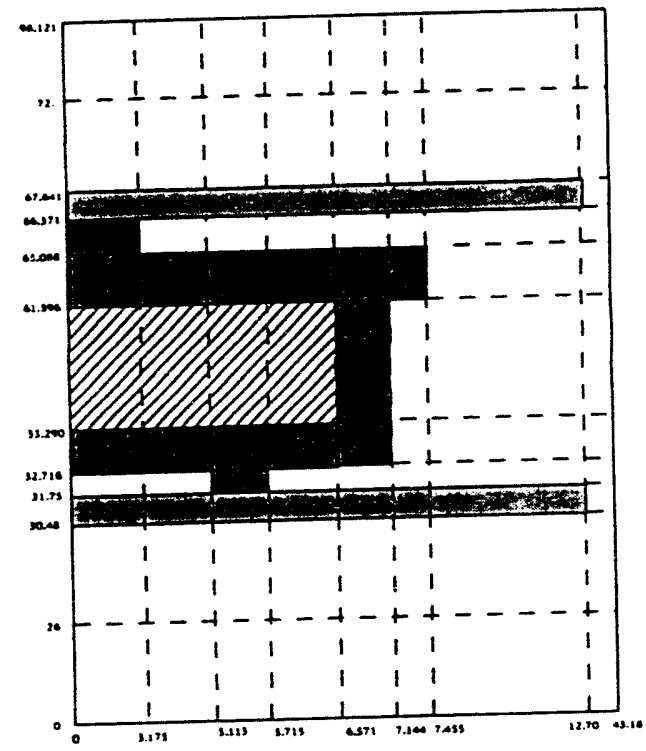

Figure 2. TWOTRAN model of the 9972 shipping cask.
WESTINGHOUSE SAVANMAH RIVER COMPANY

INTER-OFFICE MEMORANDUM

SR P Pare 26 of 34 Figure 3. Model of the 9973 cask. The unshaded areas represent shading aluminum. and the darkest shading SS-304. The composition and geometry of the interior of the PCV depends on the case being and geometry of the interior of the figure 5). Everything out to the top and bottom plates is to scale. 
WESTINGHOUSE SAYANNAH RIVER COMPANY
SAFETY TECHNOLOGY DEPARTMENT

INTER-OFFICE MEMORANDUM

\begin{tabular}{l} 
Phase 1 Criticality Analysis for ... SET Page 27 of 34 \\
\hline
\end{tabular}

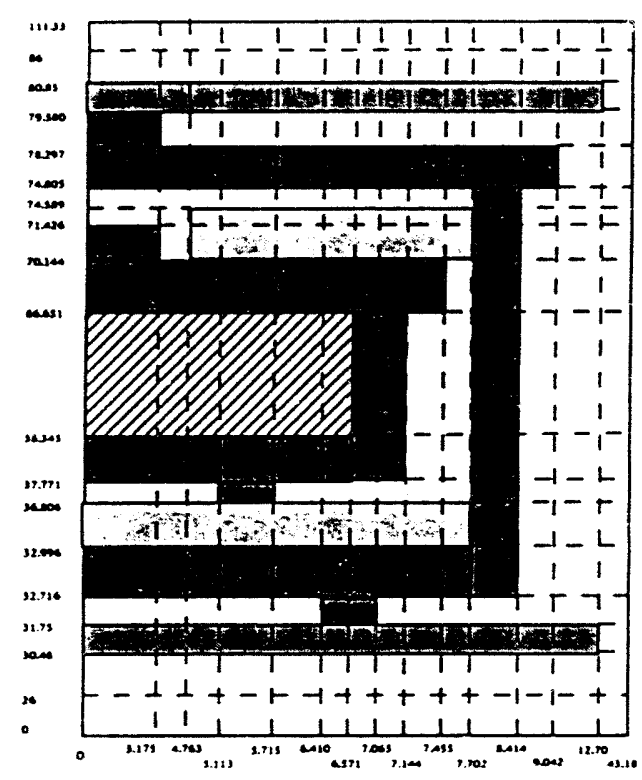

Figure 4. TWOTRAN modei of the 9973 shipping cask.
WESTINGHOUSE SAVANNAH RIVER COMPANY
SAFETY TECHNOLOGY DEPARTMENT

INTER-OFFICE MEMORANDUM

Phase 1 Criticality Analysis for ... SR Pape 28 of 34

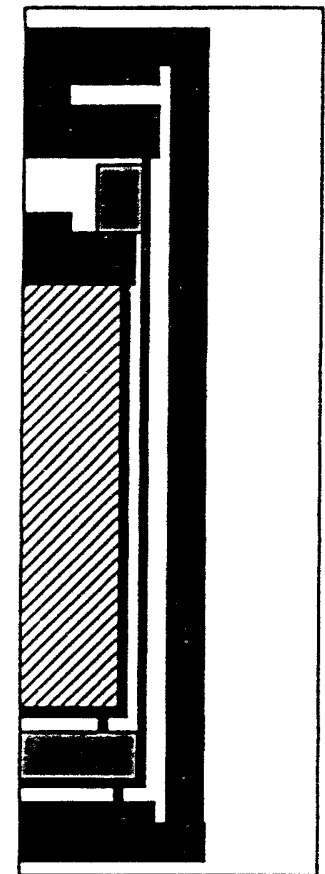



Figure 5. Model of the 9974 cask. The unshaded areas represent

water. The lightest shading indicates aluminum honeycomb. the darker

shading SS-304. And the black lead. The composition and geometry of

5). Everything out to the top and bottom plate is to scale. 


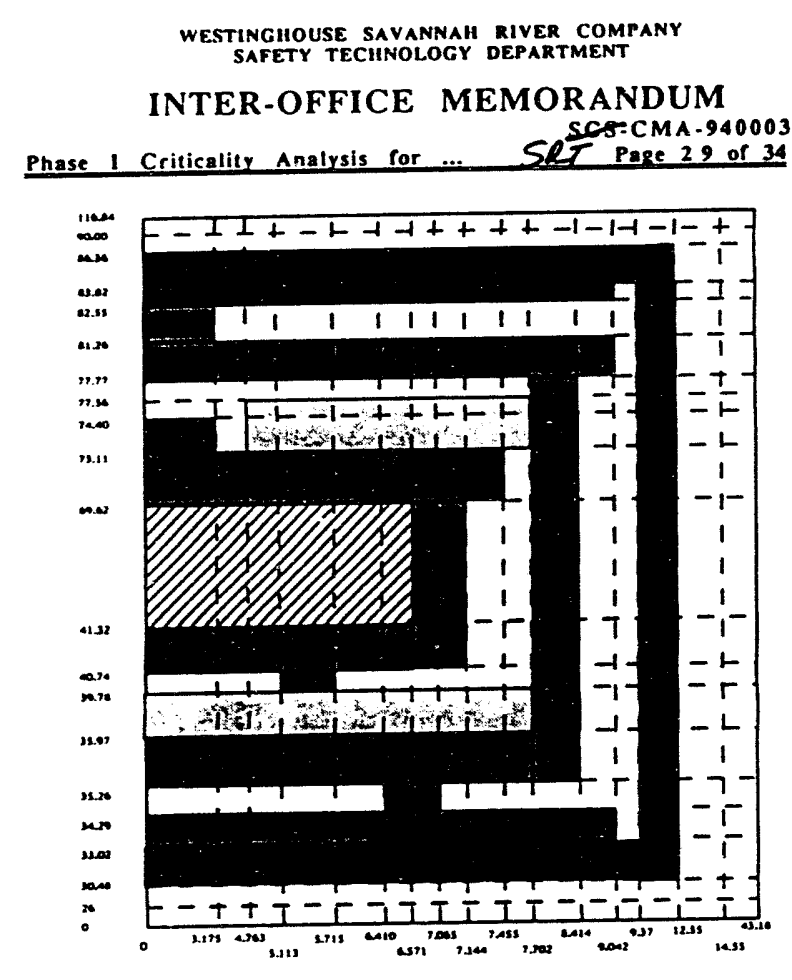

Figure 6. TWOTRAN model of the 9974 shipping cask.

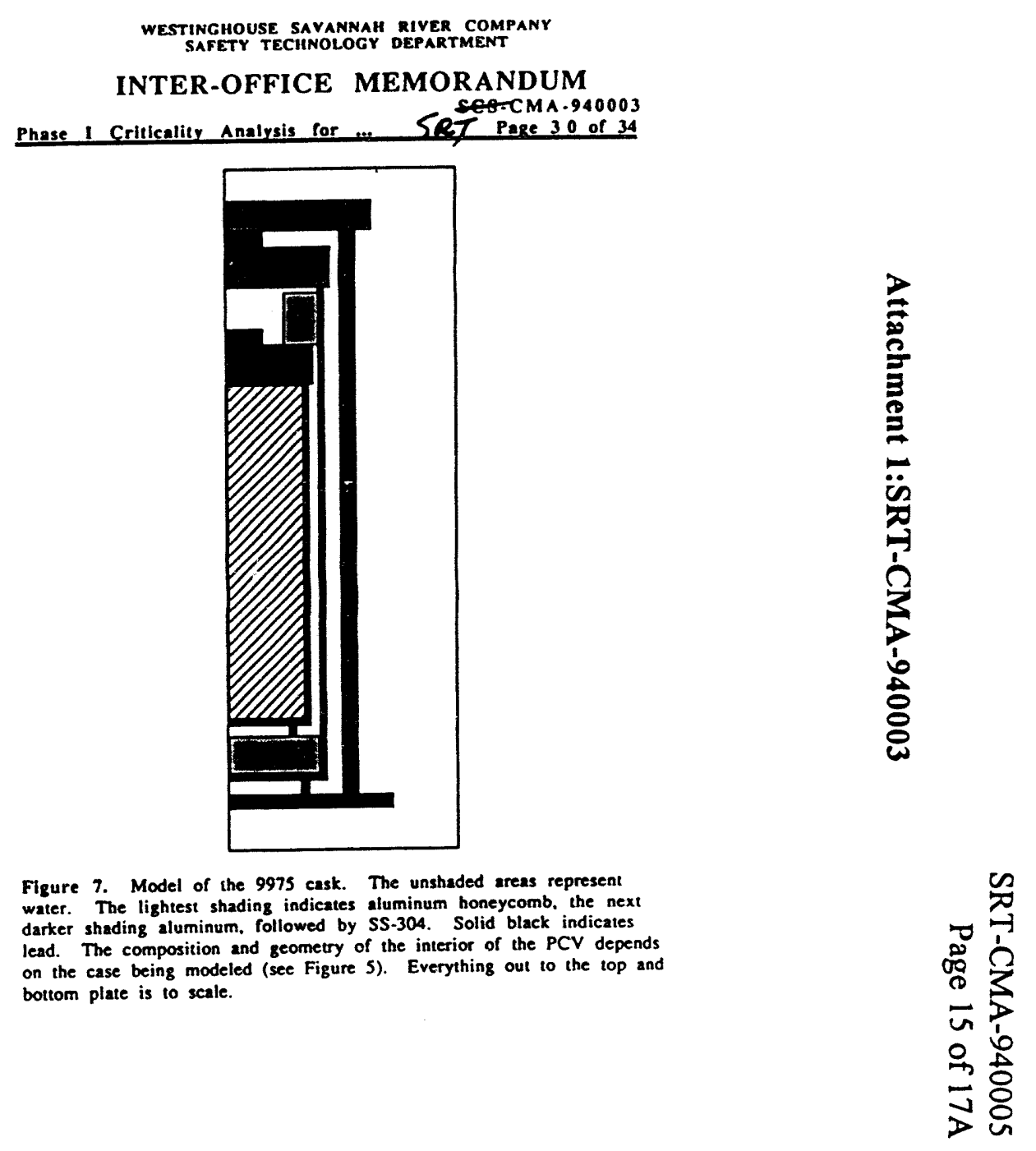


WESTINGHOUSE SAVANNAH RIVER COMPANY INTER-OFFICE MEMORANDUM

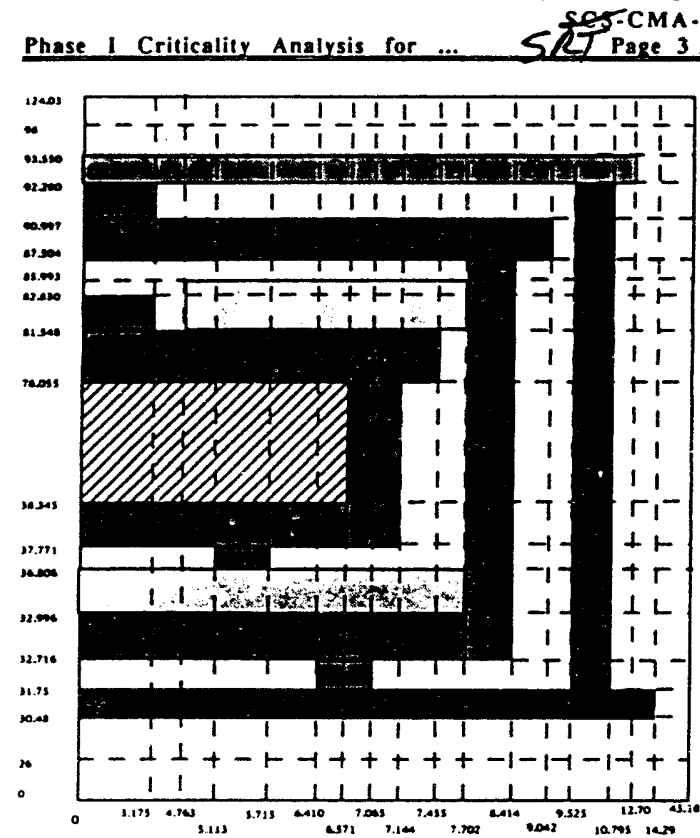

Figure 8. TWOTRAN model of the 9975 cask.
WESTINGHOUSE SAYANAAl RIVER COMPANY

INTER-OFFICE MEMORANDUM

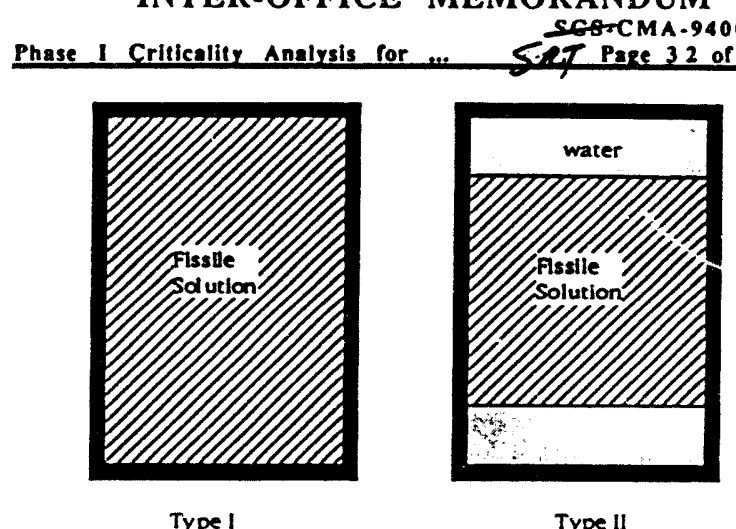

Type I

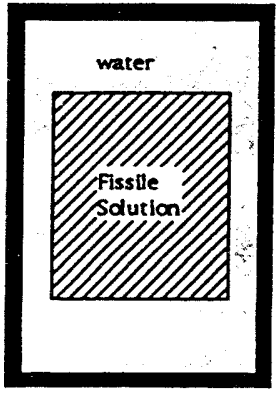

Type III

Figure 9. Illustration of the different calculation types required. The solid black region represents the PCV wall. 
WESTINGHOUSE SAYANNAH RIVER COMPANY
SAFETY TECHNOLOGY DEPARTMENT

INTER-OFFICE MEMORANDUM
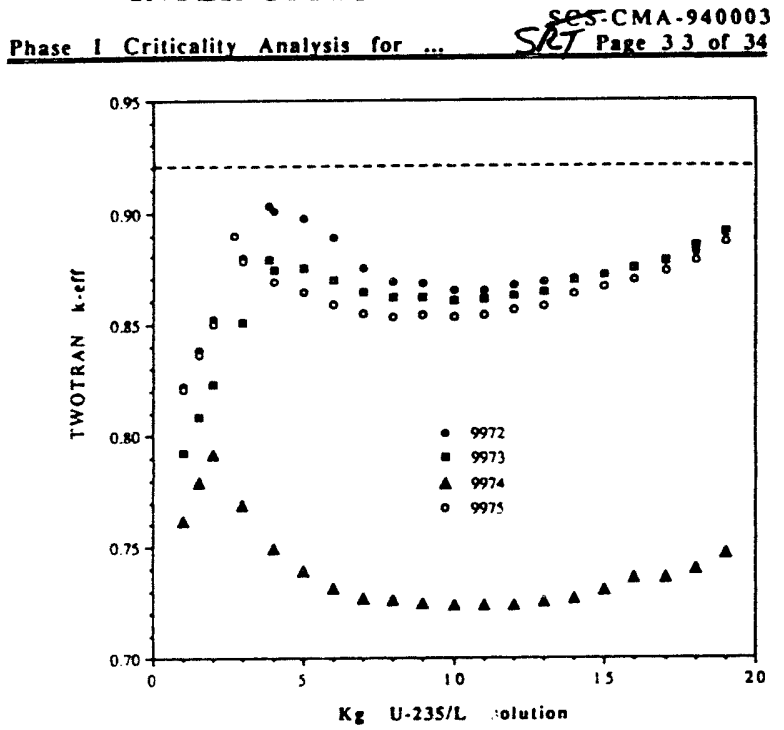

Figure 10. Results of the TWOTRAN analysis for U-235.
WESTINGHOUSE SAYANMAH RIVER COMPANY
SAFETY TECHNOLOGY DEPARTMENT INTER-OFFICE MEMORANDUM phase 1 Criticality Analysis for ... SRT Pase 34 of 34

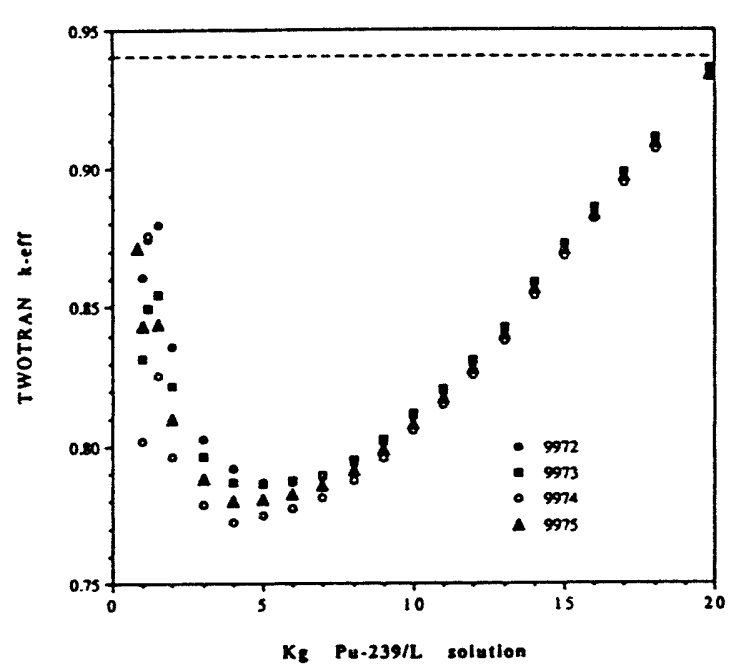

Ke Pu-239/2 solution

Figure 11. Results of the TWOTRAN analysis for Pu-239. 
1Q34

NRTSC QA Procedures

QA Program Procedures, Category 4

QAP 11-14, Rev. 0

Effective $8 / 1 / 91$

Page 8 of 8

Attachment B

Review Sheet Form

OSR 24-K7

Task title Technical Review of SCS-CMA-940003 Task number N/A Item reviewed SCS-CMA - 940003 Page 1 of 1 (Attach additional pages as necessary; marked-up pages are acceptable.)

1. Areas reviewed (identify clearly each area reviewed).

See scope on page 206

2. Approaches used to perform the review.

Seer scope on page 2 of 6

3. Questions, comments to be resolved.

None

I agree with the technical content.

I disagree with the technical content.

1 accept the conclusions and recommendations.

_ I do not accept the conclusions and recommendations for the following reasons:

Reviewer signature

Date $3 / 1,94$

Refer to NRTSC procedure 11-14, Technical Review, for additional information. 

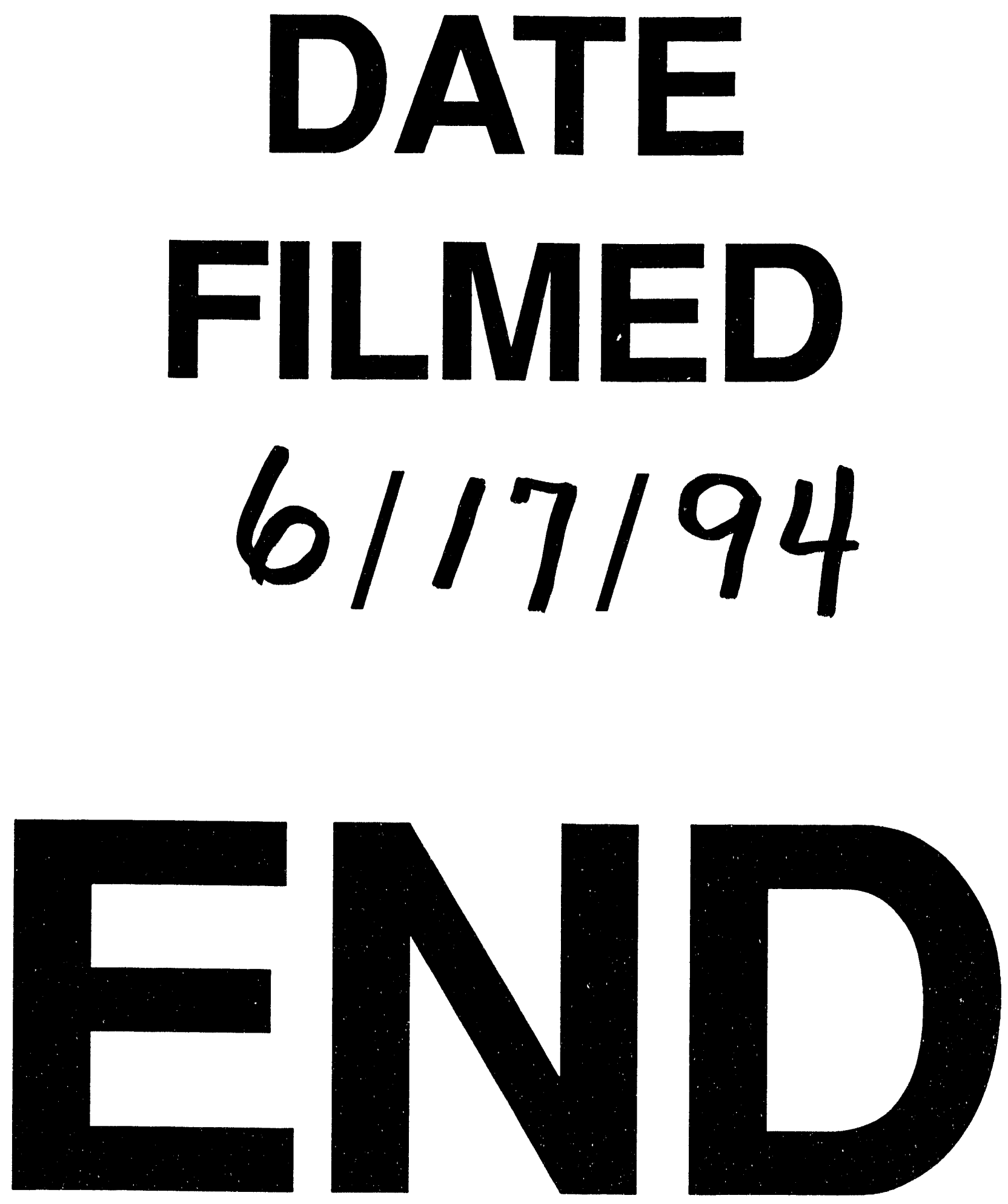
